\title{
Effects of Rice Husk and Rice Husk Charcoal on Soil Physicochemical Properties, Rice Growth and Yield
}

\author{
Anand Mishra ${ }^{1,2}$, Koungveng Taing ${ }^{1,3}$, Michael W. Hall4, Yoshiyuki Shinogi ${ }^{1}$ \\ ${ }^{1}$ Laboratory of Irrigation and Water Management, Faculty of Agriculture, Kyushu University, Fukuoka, Japan \\ ${ }^{2}$ Agricultural Engineering Division, Nepal Agricultural Research Council, Kathmandu, Nepal \\ ${ }^{3}$ Phnom Penh Municipality, Department of Agriculture, Cambodia \\ ${ }^{4}$ Department of Environmental Design, Faculty of Design, Kyushu University, Fukuoka, Japan \\ Email: *anandhansy@yahoo.com
}

How to cite this paper: Mishra, A., Taing, K., Hall, M.W. and Shinogi, Y. (2017) Effects of Rice Husk and Rice Husk Charcoal on Soil Physicochemical Properties, Rice Growth and Yield. Agricultural Sciences, 8, 1014-1032.

https://doi.org/10.4236/as.2017.89074

Received: July 17, 2017

Accepted: September 15, 2017

Published: September 18, 2017

Copyright $\odot 2017$ by authors and Scientific Research Publishing Inc. This work is licensed under the Creative Commons Attribution International License (CC BY 4.0).

http://creativecommons.org/licenses/by/4.0/

\section{(c) (i) Open Access}

\begin{abstract}
To investigate the effect of the application of rice husk (RH) and rice husk charcoal (RHC) on soil properties and rice production, pot experiment comprising of five treatments was conducted. Soil was mixed at the rate of 0 (control), $2 \%$ and $4 \%(\mathrm{w} / \mathrm{w})$ with $\mathrm{RH}$ and $\mathrm{RHC}$, respectively with randomized complete block design (RCBD). RHC incorporation had a potential to reduce the acidity of the soil, whereas, $\mathrm{RH}$ incorporation had almost no effect on the $\mathrm{pH}$ of the soil. $\mathrm{RH}$ and RHC amendment both increased the saturated hydraulic conductivity, saturated water content, plant available water and field capacity but decreased the bulk density of soil. Crop growth components at harvest revealed that the highest plant height was recorded in RH4\%. However, for the panicle length, panicle weight and number of tillers, the highest value was found in RHC2\%, $14.2 \mathrm{~cm}, 4.0 \mathrm{~g}$ and $28.8 \mathrm{~cm}$, respectively. Furthermore, number of panicle, 1000-grains weight and grain yield were also found highest in RHC2\%, $22.4 \mathrm{~g}$ and $4.41 \mathrm{t} / \mathrm{ha}$, respectively. However, for the number of grain per panicle and percentage of filled grain, the highest value was found in RH4\%, 79.0 and 88.5, respectively. The grain yield increased by $38 \%, 28 \%, 18 \%$ and $22 \%$ and the biological yield increased by $27 \%, 18 \%, 14 \%$, and $16 \%$ for $\mathrm{RHC} 2 \%$, RHC4\%, $\mathrm{RH} 2 \%$, and $\mathrm{RH} 4 \%$, respectively, compared to that of the control; however, the significant difference was found only for RHC2\% for both. The harvest index increased under all application rates of $\mathrm{RH}$ and RHC compared to that of control.
\end{abstract}

\section{Keywords}

Rice Husk, Rice Husk Charcoal, Soil Properties, Rice Growth, Rice Yield 


\section{Introduction}

Rice (Oryza sativa L.) is one of popular crop and staple food for more than half of the world's population. The yield of rice needs to annually increase by more than $1.2 \%$ to meet the rising food demand due to global rise in population and economic development [1]. On the other hand, soil organic matter (SOM) is being depleted daily, which affects the soil quality and fertility, and has become one of the major threats to agricultural productivity [2]. The soil organic matter in soil can be increased by adding plant residues such as rice husk (RH), composts, and also by adding biochar to the soil. RH is the hard dry shell that protects the outermost layer of the rice kernel [3], usually removed during the milling process, and is a by-product obtained from rice production [4]. About 770 million tons of rice husks are produced annually in Asia. In Japan only, more than 1.8 million tons per year of rice husks are produced [5]. Thus, the immense amount of annually produced $\mathrm{RH}$ needs to be effectively managed. One way to accomplish this is by directly incorporating RH into the paddy field and thereby increasing the soil organic matter. In addition, it can be converted to Rice Husk Charcoal (RHC) and then applied to the field. Application of RH or RHC to crop field not only improves the physical or chemical properties of soil but also resolve the waste disposal problem. Nowadays, RHC is receiving more interest because of its potential for carbon sequestration, and its ability for improving soil fertility and increasing crop production [6]. Biochar is a carbon rich compound produced by the pyrolysis of biomass in a limited oxygen environment. Application of biochar to soil not only improves soil fertility [7], but also increases water and nutrient retention [8].

$\mathrm{RH}$ and RHC also improve the soil condition and crop production by improving soil chemical characteristics [9] [10]. The addition of RHC to the soil was found to increase the soil $\mathrm{pH}$, available phosphorus (P), soil porosity, Plant Available Water (PAW), and also increase the exchangeable potassium (K) and magnesium (Mg). Similarly, RH contains a high content of silicon and potassium nutrients. These properties indicate $\mathrm{RH}$ has great potential to be used as a soil amendment [11]. Moreover, [12] reported that RH could be used as a soil amendment, particularly, for improving soil physical properties by improving the porosity of soil. It is reported that RH and RHC addition to paddy soil, increases the rice production [10] [13] [14] [15]. The results of biochar application to soil on crop production and soil physical properties is diverse and it depends on various factors such as application rate, feedstock used, pyrolysis temperature, crop type and soil type used [16]. Furthermore, the information on the use of RHC and RH application to rice crop and its effect on soil physical properties and rice production are still limited. It is also important to find the optimum application rate of RH and RHC for higher yield and improved soil physical properties. Hence, this study was conducted with the following two objectives 1) to qualify the effect of RH and RHC on soil properties and 2) to know the effect 
of different application rates of $\mathrm{RH}$ and $\mathrm{RHC}$ on rice production.

\section{Materials and Methods}

\subsection{Experiment Procedures}

The pot experiment was conducted from May to September, 2014 at Kyushu

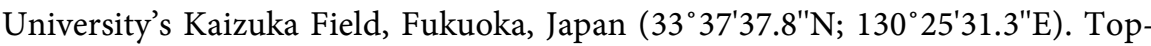
soil for this experiment $(0-20 \mathrm{~cm})$ was collected from a paddy field at the Kyu-

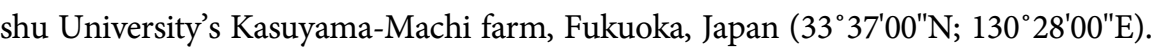
It was air dried and passed through 4-mm sieve before filling into pots. The size of pots were $70 \times 40 \times 25 \mathrm{~cm}(\mathrm{~L} \times \mathrm{W} \times \mathrm{H})$. Commercial $\mathrm{RH}$ and RHC were used for this experiment. The application rate of $\mathrm{RH}$ and RHC were $(2 \%$ and $4 \% \mathrm{w} / \mathrm{w}$, respectively), hereafter, mentioned as $\mathrm{RH} 2 \%$, $\mathrm{RH} 4 \%$, RHC2\% and $\mathrm{RHC} 4 \%$, respectively. The control pot had no amendments. The pots were arranged in a randomized complete block design (RCBD) with three replications. N: P: K (1:2:1) fertilizer was applied to ensure the sufficient nutrient supply during the experiment. The fertilizer was divided into three doses. $40 \mathrm{~g}$ per pot of fertilizer was applied before transplanting, $20 \mathrm{~g}$ was applied at the tillering stage, and finally $20 \mathrm{~g}$ was applied at the panicle initiation stage. The Rice (Oryza sativa), Yuki Hikari variety was used as the test crop. The Yuki Hikari was released in 1981 in Hokkaido, Japan and was derived from the progeny of crossed between Hokkaido landraces [17]. Eight hills per pot and one seedling of twenty-one days per hill were transplanted. All treatments received equal amount of water during this experiment.

\subsection{Characterization of Rice Husk and Rice Husk Charcoal}

Proximate and ultimate analysis such as moisture, volatile matter, fixed carbon [18] for RH and RHC were analyzed. The samples were oven dried at $110^{\circ} \mathrm{C}$ for 24 hours, and crushed in a mortar and pestle to fine powder and were sieved for characterization. The sieved samples were kept in a covered ceramic crucible and were put inside a muffle furnace at $900^{\circ} \mathrm{C}$ for 6 minutes for determination of the volatile matter. The samples were ignited at $600^{\circ} \mathrm{C}$ for 6 hours in muffle furnace for determination of ash content. Elemental $\mathrm{C}$ and $\mathrm{N}$ were analyzed by elemental analyzer (Yanaco $\mathrm{CHN}$ corder (MT-5)). The $\mathrm{pH}$ and an electrical conductivity (EC) were determined by using a $\mathrm{pH}$ meter (HORIBA LAQUAtwin B-712) and electrical conductivity meter (HORIBA LAQUAtwin B-771), respectively with the ratio of soil and water 1:5 (w/v) at standard temperature and pressure. $\mathrm{RH}$ and RHC were filled in $100 \mathrm{~cm}^{3}$ steel cylinder and was compacted manually for the determination of the bulk density. The weight of RH or RHC retained in the cylinder divided by the volume of cylinder, gave the bulk density of RH or RHC. Cation exchange capacity (CEC) of RHC was determined by using $1 \mathrm{M}$ ammonium acetate $(\mathrm{pH} 7)$ method as described by [19]. The surface functional group on RH and RHC were analyzed by Fourier Transformation Infrared Spectros- 
copy (FTIR) (FT/IR-620, JASCO).

\subsection{Soil Sampling and Analysis}

The collected soil sample was mixed with $\mathrm{RH}$ at the rate $0 \%, 2 \%$ and $4 \%(\mathrm{w} / \mathrm{w})$, likewise, the RHC amended soil was also prepared at the rate of $0 \%, 2 \%$ and $4 \%$ $(\mathrm{w} / \mathrm{w})$. The prepared soil samples were filled into a $100 \mathrm{~cm}^{3}$ steel cylinders manually and were compacted several times for soil physical properties analysis. The samples were submerged in deionized water for 24 hours until they reached a saturated condition before conducting the experiment of saturated hydraulic conductivity and water retention with three replications. The particle size distribution was determined using the pipette method [20].

\subsection{Soil Physical Properties}

The saturated hydraulic conductivity $\left(K_{s}\right)$ is the rate of movement of water within the soil. It was measured by the falling head method. The $K_{s}$ value of soil was determined by Darcy's equation [21].

$$
K_{s}=\left[\frac{a L}{A\left(t_{2}-t_{1}\right)}\right] \log \left(\frac{H_{2}}{H_{1}}\right)
$$

where $K_{s}$ is the coefficient of permeability, $a$ is the cross-sectional area of the burette, $A$ is the cross-sectional area of the soil column, $L$ is length of soil column and $\left(t_{2}-t_{1}\right)$ is the time required for the head to drop from $H_{1}$ to $H_{2}$.

The water retention data were measured and analyzed by using the RETC software based on Van Gennuchten's soil water retention model (1980) by the following equation [22].

$$
\theta=\theta_{r}+\frac{\theta_{s}-\theta_{s}}{\left[1+|\alpha h|^{n}\right]^{m}}
$$

where, $\theta$ is the soil water content $\left(\mathrm{cm}^{3} / \mathrm{cm}^{3}\right), \theta_{r}$ is the soil residual water content $\left(\mathrm{cm}^{3} / \mathrm{cm}^{3}\right), \theta_{s}$ is the soil saturated water content $\left(\mathrm{cm}^{3} / \mathrm{cm}^{3}\right), h$ is the soil water potential $(\mathrm{kPa}), \alpha$ is a scale parameter inversely proportional to the mean pore diameter $\left(\mathrm{cm}^{-1}\right), n$ and $m$ are the shape parameter of the soil water characteristic, $m=1-1 / n, 0<m<1$.

The plant available water (PAW) is the portion of water that can be efficiently utilized by the plant. PAW was calculated as the difference between volumetric water content at the field capacity and the permanent wilting point.

\subsection{Soil Chemical Properties}

The total nitrogen (TN) and total phosphorous (TP) of the soil were analyzed before planting and after harvest. The measurement of TN was determined by the indophenol method [23] and TP by the ascorbic method [24]. Each sample was digested with $\mathrm{H}_{2} \mathrm{SO}_{4}-\mathrm{H}_{2} \mathrm{O}_{2}$ following the Kjeldahl digestion method [25]. All the measurements were repeated three times. 


\subsection{Crop Growth and Yield Parameters}

Among the eight hills, plant growth and yield parameters were observed from the middle four hills of each pot. Observations on plant height $(\mathrm{cm})$, panicle length $(\mathrm{cm})$, number of grains per panicle, the number of filled (\%) and unfilled grains (\%) of panicles were recorded for each treatment at harvest. The harvested samples were sun dried. Thousand-grain weight was determined by selecting 1000 grains randomly for each treatments and weighing it on a digital balance in grams $(\mathrm{g})$. The grain yield was determined in $(\mathrm{t} / \mathrm{ha})$. Straw was oven dried at $70^{\circ} \mathrm{C}$ for 72 hours in (t/ha). Biological yield (dry matter) was determined as the sum of grain yield and straw yield $(\mathrm{t} / \mathrm{ha})$. The harvest index was determined as the ratio of economic grain yield to biological yield.

\subsection{Data Analysis}

STATISTIX 8 was used for data analysis (Analytical Software, Tallahassee, FL, USA) [26]. Analysis of Variance (ANOVA) was used to verify the statistical difference between the treatments at $P<0.05$. The means were compared by using Tukey's HSD test at $P<0.05$.

\section{Results}

\subsection{Characterization of RH, RHC, and the Soil}

The proximate analyses of the RH and RHC such as: moisture content, ash content, volatile matter, and fixed carbon are presented in Table 1 . The volatile

Table 1. Physicochemical properties of Rice husk and Rice husk charcoal.

\begin{tabular}{cccc}
\hline Elements & Rice husk $(\mathrm{RH})$ & Rice husk char (RHC) & Soil \\
\hline Proximate analysis $(\%)$ & 3.51 & 4.25 & - \\
Moisture content & 67.64 & 15.64 & - \\
Volatile matter & 17.11 & 44.87 & - \\
Ash & 11.74 & 35.24 & - \\
Fixed carbon & & & \\
Ultimate analysis $(\%)$ & 38.30 & 40.10 & 2.00 \\
C & 5.60 & 1.70 & 0.80 \\
H & 0.30 & 0.50 & 0.20 \\
$\mathrm{~N}$ & 136.60 & 87.20 & 11.60 \\
$\mathrm{C} / \mathrm{N}$ ratio & 6.80 & 10.50 & 5.90 \\
$\mathrm{pH}$ & - & 1.67 & 1.42 \\
EC $\left(\mu \mathrm{s} / \mathrm{cm}^{2}\right.$ & - & 37.4 & 26.7 \\
CEC $\left(\mathrm{cmol} \cdot \mathrm{kg}^{-1}\right)$ & 2.60 & 97.20 & 11.20 \\
$(\mathrm{BET})$ surface area $\left(\mathrm{m}^{2} \cdot \mathrm{g}^{-1}\right)$ & 2.93 & 4.28 & 1.34 \\
Total Nitrogen $(\mathrm{g} / \mathrm{Kg})$ & 0.49 & 2.01 & 1.96 \\
Total Phosphorus $(\mathrm{g} / \mathrm{Kg})$ & 0.10 & 0.17 & 1.19 \\
Bulk density $\left(\mathrm{g} / \mathrm{cm}^{3}\right)$ & & & \\
\hline
\end{tabular}

BET: Brunauer-Emmett-Teller, EC: Electrical conductivity, CEC: Cation Exchange Capacity. 
matter for RH was approximately four times higher than that of RHC. On the other hand, the ash content and fixed carbon was higher in RHC compared to RH. The RHC was rich in C as revealed by elemental analysis (Table 1). The soil used in this study had total $\mathrm{C}$ and $\mathrm{N}$ contents of $2 \%$ and $0.2 \%$, respectively, with a C/N ratio of 11.6. The total C, total $\mathrm{N}$ and C: $\mathrm{N}$ ratio of $\mathrm{RHC}$ were $40.1 \%, 0.5 \%$ and $87.2 \%$, respectively. The $\mathrm{pH}$ of RHC was higher compared to that of RH and soil. Both soil and RH were slightly acidic in nature. The CEC value for RHC was higher compared to the soil. The surface area of $\mathrm{RH}$ was much lower than that of RHC. Total Nitrogen (TN) for RH and RHC was higher to that of soil $(1.34 \mathrm{~g} / \mathrm{kg})$, whereas, the Total Phosphorus (TP) value was found higher than the soil only in RHC (Table 1). The bulk density of RHC was almost twice to that of $\mathrm{RH}$.

FTIR analysis of RH and RHC samples for surface functional groups are presented in Figure 1(a) for RH and Figure 1(b) for RHC, respectively. The spec-

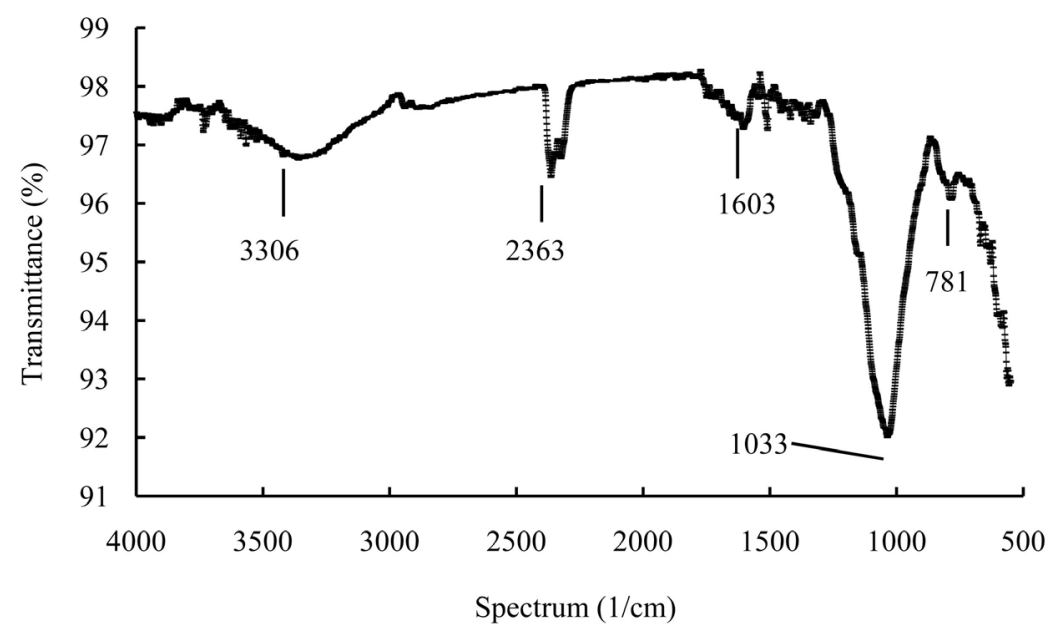

(a)

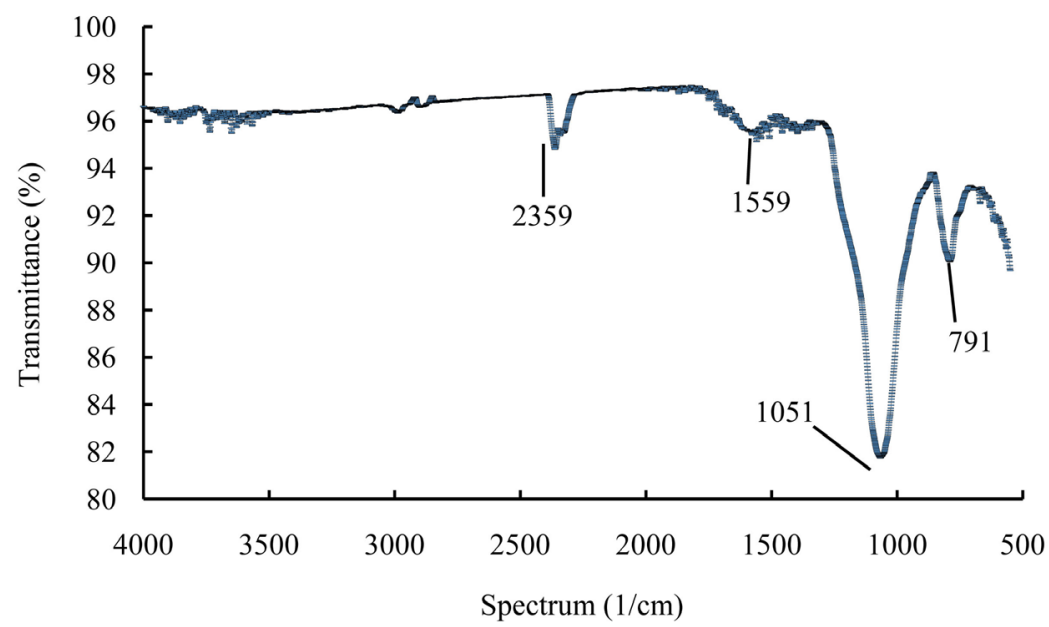

(b)

Figure 1. Fourier Transform Infrared Spectroscopy (FTIR) of (a) rice husk; (b) rice husk charcoal. 
trum of RH (Figure 1(a)) showed 5 major peaks; the peak at $3306 \mathrm{~cm}^{-1}$ corresponded to $\mathrm{O}-\mathrm{H}$ stretching carboxylic group, the peak at $2363 \mathrm{~cm}^{-1}$ corresponded to $-\mathrm{C} \equiv \mathrm{C}$ - stretching of alkynes, a peak at $1603 \mathrm{~cm}^{-1}$ correlated with $\mathrm{C}=\mathrm{C}$ phenyl ring, peak at $1033 \mathrm{~cm}^{-1}$ indicative of secondary alcohol C-C or Si-O-Si stretch, and the peak at $781 \mathrm{~cm}^{-1}$ correlated with aromatic $\mathrm{C}-\mathrm{H}$ bending. The spectrum of RHC (Figure 1(b)) showed 4 major peaks; the peak at $2359 \mathrm{~cm}^{-1}$ corresponded to $-\mathrm{C} \equiv \mathrm{C}$ - stretching of alkynes, a peak at $1559 \mathrm{~cm}^{-1}$ correlated with $\mathrm{C}=\mathrm{C}$ phenyl ring, peak at $1051 \mathrm{~cm}^{-1}$ indicative of secondary alcohol $\mathrm{C}-\mathrm{C}$ or $\mathrm{Si}-\mathrm{O}-\mathrm{Si}$ stretch, and the peak at $791 \mathrm{~cm}^{-1}$ correlated with aromatic $\mathrm{C}-\mathrm{H}$ bending.

\subsection{Soil Texture}

The soil used for this experiment contains $47.4 \%$ clay, $23.5 \%$ silt and $29.1 \%$ sand, respectively, according to the Japanese Industrial Standard [27]. The soil texture was classified as clayey soil.

\subsection{The Effect of RH and RHC on Soil Physical Properties}

\subsubsection{Saturated Hydraulic Conductivity and Bulk Density}

The application of RH and RHC to soil increased the saturated hydraulic conductivity (Ks) (Figure 2). The higher the application rates of RH or RHC, higher the value of Ks compared to that of control. However, significant difference was only found in RH4\% $(p<0.05)$. RH and RHC both have the potential to decrease the bulk density (Figure 3 ). The bulk density of soil under various application rates ranges from 1.19 to $0.98 \mathrm{~g} / \mathrm{cm}^{3}$. The bulk density was decreased by $7 \%, 14 \%, 11 \%$ and $21 \%$ for $\mathrm{RHC} 2 \%, \mathrm{RHC} 4 \%, \mathrm{RH} 2 \%$ and $\mathrm{RH} 4 \%$, respectively compared to that of the control. The bulk density was significantly decreased at $p<0.05$ for all application rates of RH and RHC compared to that of the control.

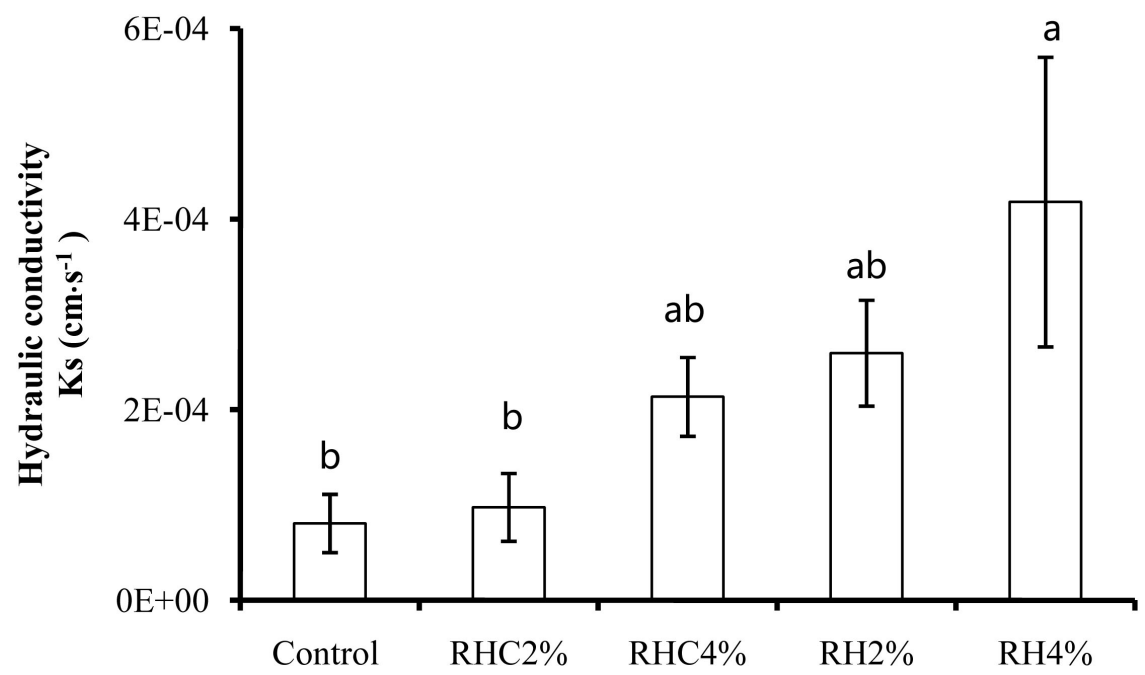

Figure 2. The hydraulic conductivity as influenced by treatments. The vertical bars indicates mean \pm standard error. 


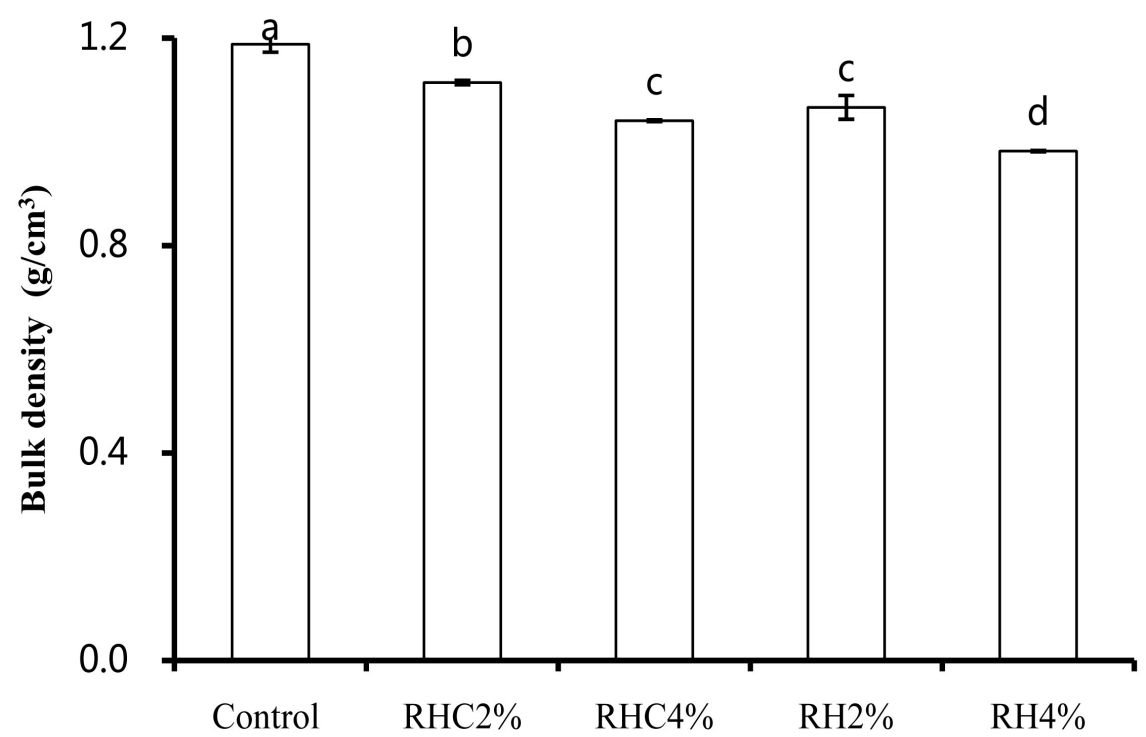

Figure 3. The bulk density as influenced by treatments. The vertical bars indicates mean \pm standard error.

\subsubsection{Water Retention Characteristics}

The water retention characteristics of soil under different application rate of $\mathrm{RH}$ and RHC are shown in Figure 4. The RH and RHC amended soils differed in $\alpha$, a fitting parameter associated with the Van Genuchten equation (Table 2). The value of $\alpha$ increased with the increase in application rates of RH and RHC. Similarly, the value of $\mathrm{n}$ fitting parameter (representing the steepness of the retention curve) for RHC2\% was found higher than that of RHC4\%. However, for RH, the value of $\mathrm{n}$ fitting parameter increased with increased in the $\mathrm{RH}$ amendment rate. The values of $\theta_{s}$ (saturated water content) and $\theta_{r}$ (residual water content) correlated with the application rates of RH and RHC.

\subsubsection{Plant Available Water (PAW)}

The PAW at different application rates of RH and RHC is shown in Figure 5. The all application rates of RH and RHC amendment increased the PAW. It was increased by $8 \%, 13 \%, 2 \%$, and $12 \%$ for $\mathrm{RHC} 2 \%$, RHC $4 \%, \mathrm{RH} 2 \%$, and $\mathrm{RH} 4 \%$. The significant difference $(p<0.05)$ was not observed for PAW among the treatments.

\subsection{The Effect of RH and RHC on Soil Chemical Properties}

\subsubsection{Soil pH}

The $\mathrm{pH}$ of RH and RHC was higher compared to that of the soil. Figure 6 shows that, the RHC increased the $\mathrm{pH}$ of the soil, whereas, $\mathrm{RH}$ has almost no effect on soil $\mathrm{pH}$. The $\mathrm{pH}$ increased by 0.1 units and 0.2 units for the $\mathrm{RHC} 2 \%$ and RHC4\%, respectively. The result showed that the $\mathrm{pH}$ of the soil was strongly correlated with the application rate of RHC. However, a significant difference was found only for RHC4\% compared to control. 


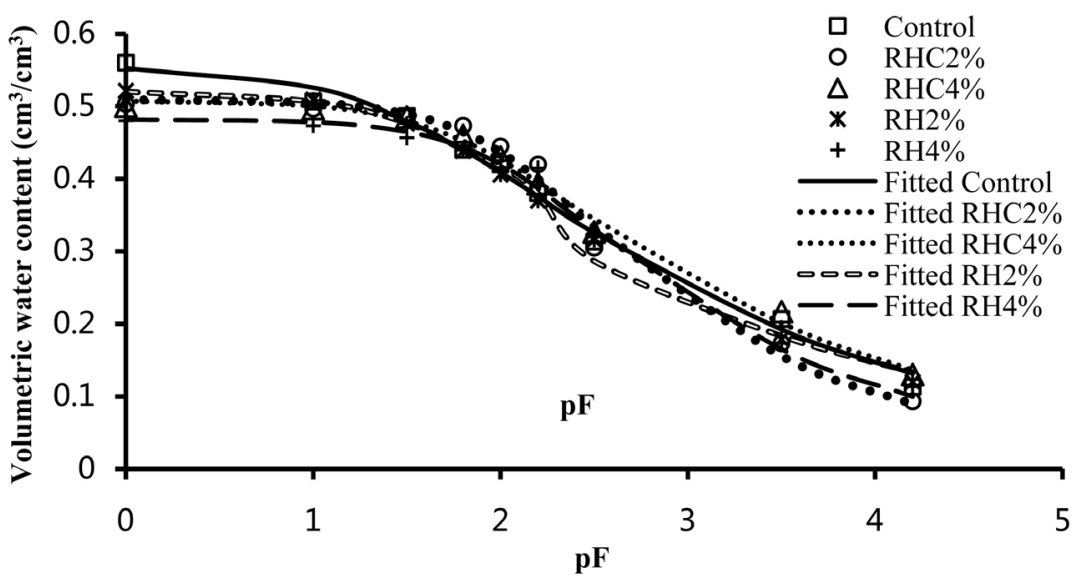

Figure 4. The observed and fitted soil water retention characteristic curve as influenced by treatments. $\mathrm{pF}$ represents the logarithmic value of water suction/pressure head.

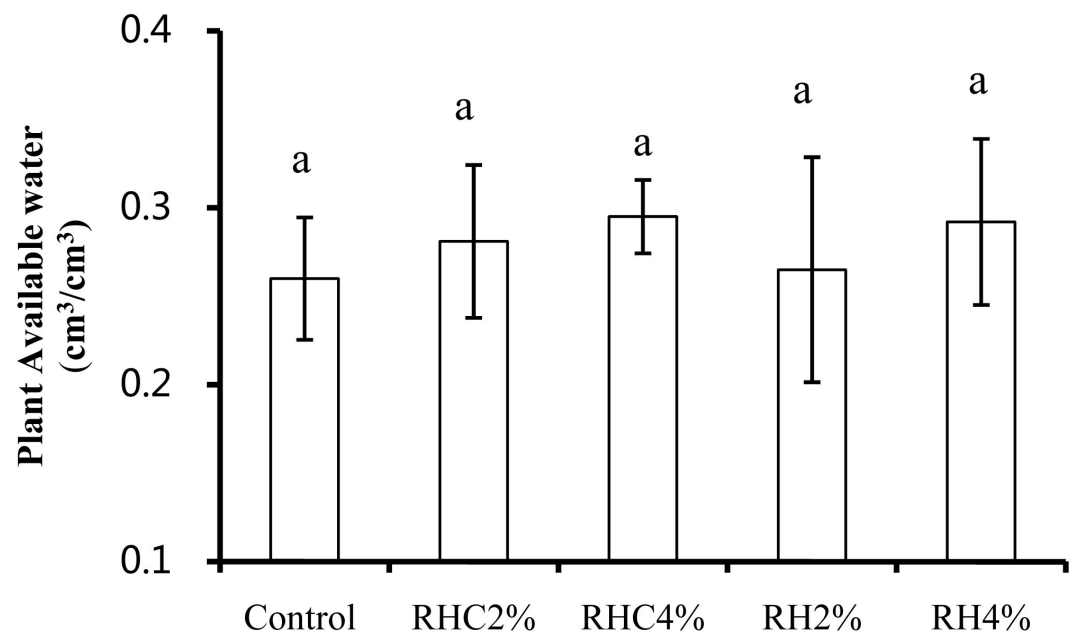

Figure 5. The Plant available water (PAW) as influenced by treatments. The vertical bars indicates mean \pm standard error.

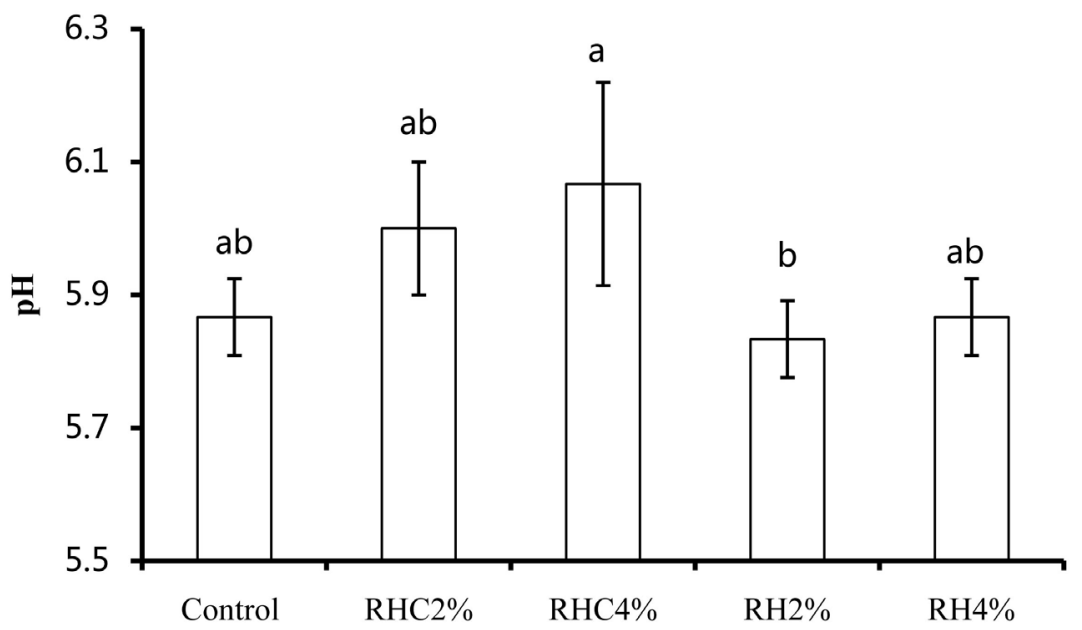

Figure 6. The soil $\mathrm{pH}$ as influenced by treatments. The vertical bars indicates mean \pm standard error. 
Table 2. Van Genuchten fitting parameters for water retention. Data compared for soil and treatments.

\begin{tabular}{cccccc}
\hline \multirow{2}{*}{ Treatment } & $\theta_{s}$ & $\theta_{\boldsymbol{r}}$ & $\boldsymbol{\alpha}$ & \multirow{2}{*}{$\boldsymbol{\alpha}$} & $\boldsymbol{R}^{2}$ \\
\cline { 2 - 4 } & $\mathrm{cm}^{3} / \mathrm{cm}^{3}$ & $\mathrm{~cm}^{3} / \mathrm{cm}^{3}$ & $\mathrm{~cm}^{-1}$ & & \\
\hline Control & 0.447 & 0.078 & 0.007 & 1.240 & 0.987 \\
RHC2\% & 0.481 & 0.082 & 0.006 & 2.070 & 0.983 \\
RHC4\% & 0.492 & 0.097 & 0.009 & 1.300 & 0.993 \\
RH2\% & 0.486 & 0.078 & 0.007 & 1.640 & 0.992 \\
RH4\% & 0.507 & 0.090 & 0.008 & 2.050 & 0.977 \\
\hline
\end{tabular}

$\theta_{\dot{s}}$ soil saturated water content, $\theta_{\dot{r}}$ soil residual water content, $\alpha$ : scale parameter, $n$ : shape fitting parameter.

\subsubsection{Total Nitrogen (TN)}

The TN of the soil at harvest is shown in Figure 7. The result revealed that the TN value was higher for both RHC application rates, whereas, the TN values were lower for both RH application rates compared to that of the control. The TN content after harvesting ranges from $1.35 \mathrm{~g} / \mathrm{kg}$ to $1.45 \mathrm{~g} / \mathrm{kg}$, and the highest value was found in the application of RHC4\% and lowest for RH4\%. However, significant difference among the treatments was not found for TN after harvesting.

\subsubsection{Total Phosphorus (TP)}

The TP of the soil at different application rates of RH and RHC is shown in Figure 8 . The value of TP of the soil ranges from $2.20 \mathrm{~g} / \mathrm{kg}$ to $2.54 \mathrm{~g} / \mathrm{kg}$. The highest value of TP was found in RHC4\% and the lowest was found in the control. No significant difference among the treatment was found in this study $(p<$ 0.05).

\subsection{The Effect of RH and RHC on Crop Growth and Yield Components}

The panicle length was found highest in treatment RHC2\% followed by RHC4\% (Table 3). The lowest value was found in the treatment RH4\%. However, no significant difference $(p \leq 0.05)$ was found among the treatments for panicle length in all RHC and RH application rates. The highest plant height was found for the treatment $\mathrm{RH} 4 \%$ and the lowest $81.7(\mathrm{~cm})$ was discovered in the control at harvest (Table 3). However, a significant difference $(p<0.05)$ was found only for the treatment RH4\% for plant height. The highest tiller number was found in the treatment RHC2\% (Table 3). The tiller number for RHC4\%, RH2\%, and RH4\% was lower than that of the control. The lowest value for tiller number was found in RH4\%. No significant difference was found among the treatments for number of tiller. The highest number of grains per panicle was realized in RH4\%, and lowest in RH2\% (Table 4). The number of grains per panicle is correlated with the amendment rate of RHC. However, no significant difference $(p<0.05)$ was observed for number of grains per panicle compared to that of control. The 


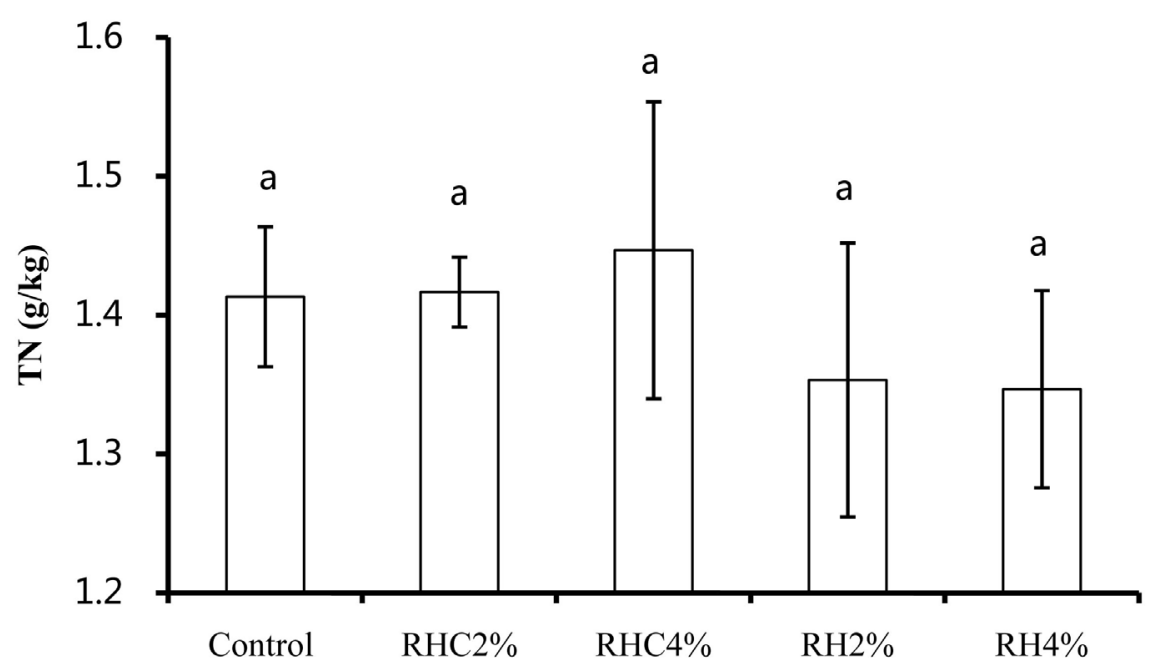

Figure 7. The TN value as influenced by treatments. The vertical bars indicates mean \pm standard error.

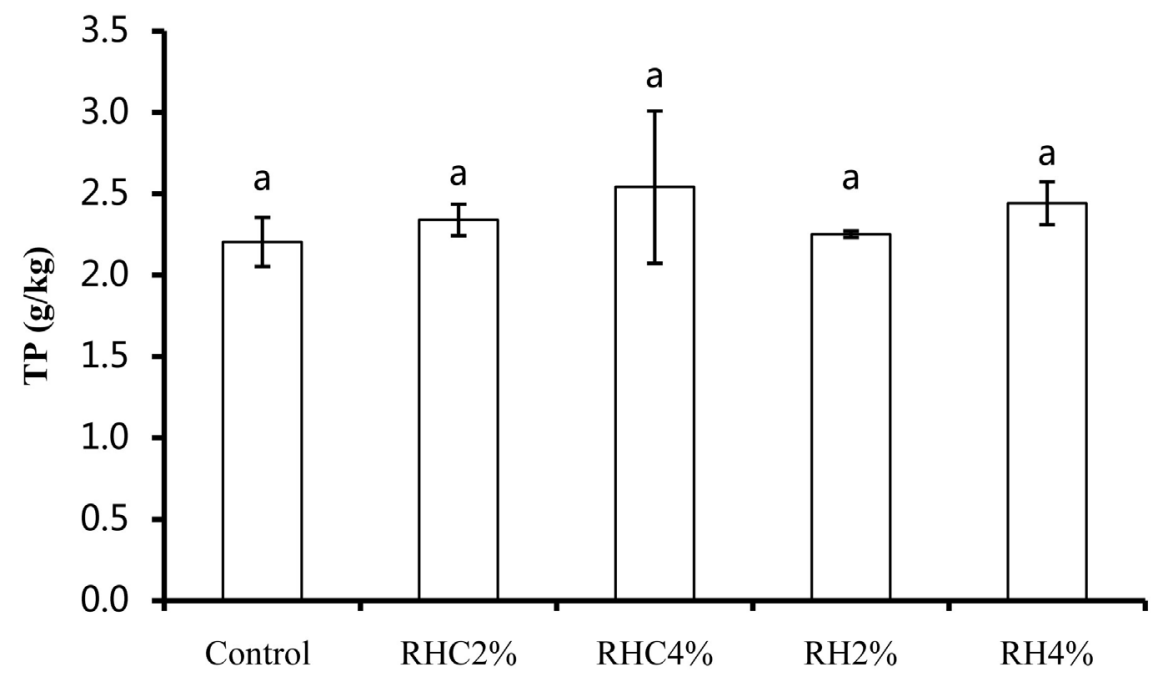

Figure 8 . The TP of soil as influenced by treatments. The vertical bars indicates mean \pm standard error.

Table 3. Growth components of rice as affected by the application of rice husk $(\mathrm{RH})$ and rice husk charcoal (RHC).

\begin{tabular}{ccccc}
\hline \multicolumn{5}{c}{ Average } \\
\hline Treatment & Panicle length $(\mathrm{cm})$ & Panicle weight $(\mathrm{g})$ & Height $(\mathrm{cm})$ & Tiller number \\
\hline Control & $13.5 \pm 0.5$ & $3.4 \pm 0.4$ & $81.7 \pm 1.7(\mathrm{~b})$ & $26.5 \pm 1.4$ \\
RHC2\% & $14.2 \pm 0.8$ & $4.0 \pm 0.3$ & $83.8 \pm 2.0(\mathrm{ab})$ & $28.8 \pm 3.9$ \\
RHC4\% & $13.9 \pm 0.2$ & $3.7 \pm 0.4$ & $83.1 \pm 0.7(\mathrm{ab})$ & $24.9 \pm 1.9$ \\
RH2\% & $13.8 \pm 0.1$ & $3.4 \pm 0.2$ & $83.2 \pm 0.5(\mathrm{ab})$ & $25.8 \pm 4.0$ \\
RH4\% & $13.2 \pm 0.2$ & $3.7 \pm 0.2$ & $85.8 \pm 1.3(\mathrm{a})$ & $24.8 \pm 2.4$ \\
\hline
\end{tabular}

Values followed by the same letter within a column indicates no significant difference at 0.05 level. 
Table 4. Yield and yield components of rice as affected by the application of rice husk $(\mathrm{RH})$ and rice husk charcoal (RHC).

\begin{tabular}{|c|c|c|c|c|c|}
\hline \multicolumn{6}{|c|}{ Average } \\
\hline Treatment & $\begin{array}{l}\text { No. of } \\
\text { grains per } \\
\text { panicle }\end{array}$ & $\begin{array}{c}\text { Filled } \\
\text { grain (\%) }\end{array}$ & $\begin{array}{l}\text { Panicle } \\
\text { number } \\
\text { (per hill) }\end{array}$ & $\begin{array}{c}1000 \\
\text { grain-weight } \\
\text { (g) }\end{array}$ & Yield (t/ha) \\
\hline Control & $71 \pm 8.7$ & $86.1 \pm 2.5$ & $22.2 \pm 1.6$ & $21.0 \pm 0.3$ & $3.18 \pm 0.04(b)$ \\
\hline RHC2\% & $75 \pm 7.2$ & $88.0 \pm 0.5$ & $25.8 \pm 2.9$ & $22.4 \pm 0.5$ & $4.41 \pm 0.17$ (a) \\
\hline $\mathrm{RHC} 4 \%$ & $76 \pm 8.1$ & $86.8 \pm 6.5$ & $20.7 \pm 1.1$ & $22.0 \pm 0.8$ & $4.08 \pm 0.81(\mathrm{ab})$ \\
\hline RH2\% & $70 \pm 2.7$ & $85.4 \pm 4.0$ & $24.8 \pm 1.6$ & $21.4 \pm 0.6$ & $3.75 \pm 0.16(\mathrm{ab})$ \\
\hline RH4\% & $79 \pm 2.5$ & $88.5 \pm 1.9$ & $21.3 \pm 3.7$ & $22.2 \pm 0.2$ & $3.88 \pm 0.17(\mathrm{ab})$ \\
\hline
\end{tabular}

Values followed by the same letter within a column indicates no significant difference at 0.05 level.

percentage of filled grain increased under the application rate of RH2\%, RHC4\% and $\mathrm{RH} 4 \%$. The lowest percentage of filled grain was apparent at $\mathrm{RH} 2 \%$, and the highest was attained at RH4\% (88.5), and followed by RHC2\% (88.0), RHC4\%, and the control, respectively (Table 4). RHC2\%, RHC4\% and RH4\%, had a positive effect to increase the percentage of filled grain. However, the percentage of filled grain was not significantly affected by the application rate of RH or RHC. The maximum weight 22.4 (g) of 1000-grain was found for RHC2\%, and the minimum weight 21.0 (g) was obtained for the control (Table 4). The result showed that both RH and RHC application tends to increase the weight of 1000-grain.The result showed RH and RHC application influenced the rice yield (Table 4). It ranges from 3.18 to $4.41 \mathrm{t} / \mathrm{ha}$, and the maximum yield was found in RHC2\%, and the minimum was observed for the control. It increased by $38 \%$, $28 \%, 18 \%$ and $22 \%$ for $\mathrm{RHC} 2 \%$, RHC $4 \%$, RH $2 \%$ and $\mathrm{RH} 4 \%$, respectively, compared to that of the control. However, a significant difference was only observed in RHC2\% compared to the control. The biological yield increased under all application rates of RH and RHC compared to that of the control (Figure 9). The biological yield ranges from 6.05 to $7.70 \mathrm{t} / \mathrm{ha}$, and the maximum was found at RHC2\% and minimum for the control. The biological yield increased by $27 \%$, $18 \%, 14 \%$, and $16 \%$ for $\mathrm{RHC} 2 \%, \mathrm{RHC} 4 \%, \mathrm{RH} 2 \%$, and $\mathrm{RH} 4 \%$, respectively, compared to that of the control; however, the significant difference was found only for RHC2\%. The harvest index increased under all application rates of RH and RHC compared to that of the control (Figure 10). The highest harvest index (57.2\%) was uncovered at RHC2\% and the lowest (52.6\%) for the control. The harvest index for RHC2\%, RHC4\%, RH2\% and RH4\% increased by 9\%, 7\%, 3\% and $5 \%$, compared to that of the control. However, a significant difference was not found among the treatments for harvest index.

\section{Discussions}

\subsection{Characterization of Rice Husk and Rice Husk Charcoal}

The proximate analysis of $\mathrm{RH}$ and $\mathrm{RHC}$ indicates $\mathrm{RH}$ has more volatile matter 


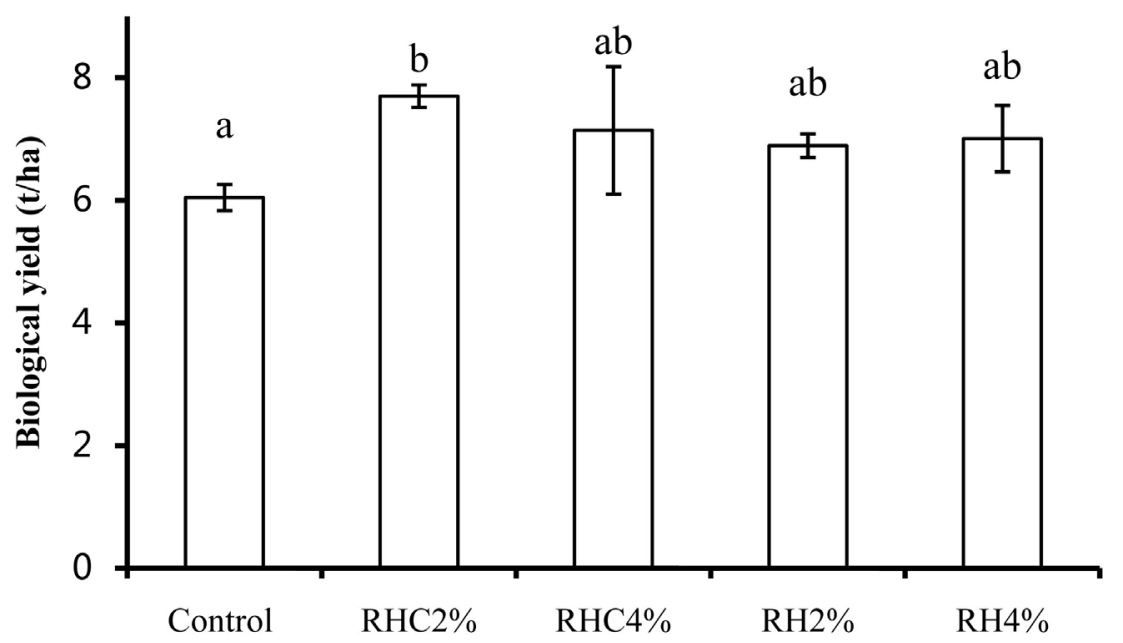

Figure 9. The biological yield ( $\mathrm{t} / \mathrm{ha}$ ) as influenced by treatments. The vertical bars indicates mean \pm standard error.

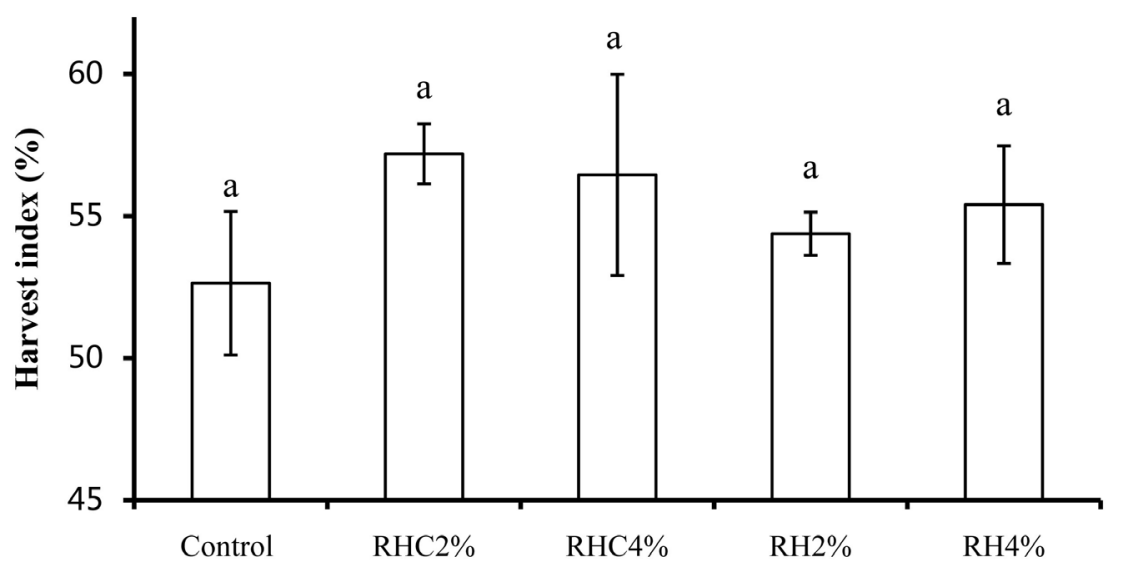

Figure 10. The harvest index as influenced by treatments. The vertical bars indicates mean \pm standard error.

and less fixed carbon, whereas, RHC has more fixed carbon but less volatile matter, consistent with [28]. They found that a higher pyrolysis temperature resulted in higher fixed carbon content. At a higher pyrolysis temperature, more volatiles matters are removed, which resulted more fixed carbon in the char particle. Furthermore, RHC produced at $600^{\circ} \mathrm{C}, 800^{\circ} \mathrm{C}$ and $1000^{\circ} \mathrm{C}$ pyrolysis temperatures had $26.37 \%, 34.33 \%$ and $38.88 \%$ fixed carbon; $51.7 \%, 53.9 \%$ and $56.1 \%$ ash content and $21.9 \%, 11.7 \%$ and $5.0 \%$ volatile matter, respectively. The volatile matter and fixed carbon for RHC in our study were 15.64 and 35.24, respectively, which confirms that the RHC used in this experiment was produced at temperature $\left(600^{\circ} \mathrm{C}-800^{\circ} \mathrm{C}\right)$ [28]. The FTIR analysis of RHC revealed that there was an absence of the hydroxyl group [29] [30]. The absence of acidic functional groups makes RHC alkaline in nature. As the RHC is alkaline it can more effectively decrease the soil acidity compared to RH as reported by [31] [32] [33] [34]. Similar result was found in this the experiment also, the soil $\mathrm{pH}$ increased 
for $\mathrm{RHC} 2 \%$ and $\mathrm{RHC} 4 \%$, whereas, $\mathrm{RH}$ had almost no effect on the $\mathrm{pH}$ of the soil. Increase in soil $\mathrm{pH}$ makes the higher availability of nutrients to the plants and thereby improving the plant growth. The increase in soil $\mathrm{pH}$ can also improve CEC and base cation of soil [35] [36].

\subsection{The Effect of RH and RHC on Soil Physical Properties}

Various researchers have found that soil with RH and RHC application improves crop productivity by enhancing soil physical properties [4] [10] [31] [34] [37] [38]. The bulk density of biochar is low but the porosity is high compared to soil, the porous nature of biochar helps to hold more air and water and thereby decreasing the soil bulk density [39]. Due to decrease in bulk density of the amended soils, the water holding capacity of soil was increased and enhance the root development as well as soil microbial activity [9] [40]. The reduction in bulk density by application of RH and RHC was also found in the authors' experiment at all application rates. The bulk density decreased as the porosity of the soil increased. As the porosity of the soil increased, the Ks and PAW of the soil increased. The bulk density and porosity are inversely co-related. The application of RH and RHC amendment to soil decreased the soil compaction. The result is also consistence with the latest studies of [4] who reported that the $\theta_{s}$ and the PAW increased for the amended soil with the application of RHC, the PAW increased by $12 \%, 20 \%$, and $31 \%$ under application of RHC $2 \%, 4 \%$, and $6 \%$.

\subsection{The Effect of RH and RHC on Crop Growth and Yield Components}

The RH and RHC demonstrated positive responses on plant growth and yield components. Similarly, grain yield and biological yield increased for all application rates of RHC and RH compared to that of the control. The increase in the number of tiller in RHC $2 \%$ can be due to the extra nutrient available to the plant due to increased water holding capacity of soil [36] [41]. Application of biochar to soil enhances the soil physical properties and also increases the nutrient supply to plant [42]. Due to high surface area of RHC, the adsorption space will be more for water and nutrient retention [43]. The increase in crop and biological yield is possibly due to the increase in hydraulic characteristics, and also biochar's property to retain the plant nutrient due to high CEC and high porosity. The RH and RHC were found to be rich in C and other major plant nutrients in the soil [44]. The result is consistent with the recent study by [9] [45] in which, they reported that the grain yield increased by $12 \%, 14 \%$ and $33 \%$ compared to that of the control by the addition of RHC at the application rate of $10 \mathrm{t} / \mathrm{ha}, 40 \mathrm{t} / \mathrm{ha}$ and $41.5 \mathrm{t} / \mathrm{ha}$. Furthermore [43] [45] reported that, the nutrients are more available to plant at a neutral $\mathrm{pH}$ which could have increase the yield of crop. The grain yield and biological yield decreased for RHC4\%. The possible reason for the decrease in yield may have been due to the high $\mathrm{C} / \mathrm{N}$ ratio of RHC significantly increased the $\mathrm{C} / \mathrm{N}$ ratio of the soil, which could have caused 
immobilization of $\mathrm{N}$ in the soil and $\mathrm{N}$-deficiency to the plant [46] [47]. Another possible reason for the decrease in yield and biological yield might have been due to aluminum deficiency [47] [48]; however, the authors' data is insufficient to support these assumptions. The grain yield increased by $18 \%$ and $22 \%$, and biological yield increased by $14 \%$ and $16 \%$ under the treatment of $\mathrm{RH} 2 \%$ and RH4\%, respectively in this study which is consistent with the finding of [15] who found that the application of RH not only improve the soil physical properties but also grain yield and biological yield. The grain yield of rice increased by $10 \%$, $23 \%, 38 \%$, and $42 \%$ in the first year, and by $9 \%, 21 \%, 33 \%$ and $38 \%$ in the second year by the application of $\mathrm{RH}$ at the rate of $2.4 \mathrm{t} / \mathrm{ha}, 4.8 \mathrm{t} / \mathrm{ha} 7.2 \mathrm{t} / \mathrm{ha}$, and $9.6 \mathrm{t} / \mathrm{ha}$, respectively. In addition, the biological yield increased by $11 \%, 28 \%$, $37 \%$, and $39 \%$ in first year and $8 \%, 27 \%, 32 \%$ and $33 \%$ in second year, respectively.

\section{Conclusion}

This study demonstrates some of the beneficial effects of RH and RHC as an organic amendment for sustainable agriculture. Incorporating $\mathrm{RH}$ and $\mathrm{RHC}$ amendment assisted in modifying and improving soil physical properties. Furthermore, RH and RHC also increased the field capacity and available water because both increase the porosity of the amended soil. Meanwhile, soil bulk density decreased. The application of RHC also increased the $\mathrm{pH}$, and demonstrated the ability to reduce the acidity of the soil, whereas, RH had almost no effect on soil $\mathrm{pH}$ of the tested soil. The grain yield increased by $38 \%, 28 \%, 18 \%$ and $22 \%$ and the biological yield increased by $27 \%, 18 \%, 14 \%$, and $16 \%$ for RHC $2 \%$, RHC4\%, RH2\%, and RH4\%, respectively, compared to that of the control; however, the significant difference was found only for RHC2\% for both.The harvest index increased under all application rates of RH and RHC compared to that of control. The effects of RHC addition were not proportional to the application rates. Higher rice yield was observed in RHC2\%. Reduction in crop yield was found in RHC4\%. In contrast, the grain yield and biology yield correlated with the amendment rate of RH. Since the rice yield decreased at RHC4\%, but for the $\mathrm{RH}$ the yield tended to increase at $\mathrm{RH} 4 \%$. In conclusion, for rice cultivation RHC2\% is the proper rate, but there is still a possibility to increase the application rate above $4 \%$ for $\mathrm{RH}$ to increase rice yield. Long-term field studies are needed to determine the optimum RH and RHC application rates for increasing rice production and improving the soil physical properties.

\section{Acknowledgements}

We express our thanks to Ministry of Education, Culture, Sports, Science and Technology (MEXT) for the financial support for this experiment.

\section{Author Contributions}

A. Mishra and K. Taing designed, performed the experiment and analyzed the 
data. A. Mishra wrote the manuscript. M. W. Hall checked the manuscript. Y. Shinogi designed, supervised and checked the manuscript.

\section{References}

[1] Normile, D. (2008) Reinventing Rice to Feed the World. Science, 321, 330-333. https://doi.org/10.1126/science.321.5887.330

[2] Lal, R. (2009) Soils and Food Sufficiency. A Review. Agronomy for Sustainable Development, 29, 113-133. https://doi.org/10.1051/agro:2008044

[3] Aderolu, A.Z., Iyayp, E.A. and Onilude, A.A. (2007) Changes in Nutritional Value of Rice Husk during Trichoderma viride Degradation. Bulgarian Journal of Agricultural Science, 13, 583.

[4] Lu, S.G., Sun, F.F. and Zong, Y.T. (2014) Effect of Rice Husk Biochar and Coal Fly Ash on Some Physical Properties of Expansive Clayey Soil (Vertisol). Catena, 114, 37-44. https://doi.org/10.1016/j.catena.2013.10.014

[5] Ministry of Agriculture, Forestry and Fisheries, Crops statistics, Crops Investigation, Rice Plant (2013)

http://www.maff.go.jp/j/tokei/kouhyou/sakumotu/sakkyou_kome/index.html\#r

[6] Kookana, R.S., Sarmah, A.K., Van Zwieten, L., Krull, E. and Singh, B. (2011) 3 Biochar Application to Soil: Agronomic and Environmental Benefits and Unintended Consequences. Advances in Agronomy, 112, 103-143. https://doi.org/10.1016/B978-0-12-385538-1.00003-2

[7] Sohi, S.P. (2012) Carbon Storage with Benefits. Science, 338, 1034-1035.

[8] Glaser, B., Lehmann, J. and Zech, W. (2002) Ameliorating Physical and Chemical Properties of Highly Weathered Soils in the Tropics with Charcoal-A Review. Biology and Fertility of Soils, 35, 219-230. https://doi.org/10.1007/s00374-002-0466-4

[9] Zhang, A., Cui, L., Pan, G., Li, L., Hussain, Q., Zhang, X. and Crowley, D. (2010) Effect of Biochar Amendment on Yield and Methane and Nitrous Oxide Emissions from a Rice Paddy from Tai Lake Plain, China. Agriculture, Ecosystems \& Environment, 139, 469-475. https://doi.org/10.1016/j.agee.2010.09.003

[10] Asai, H., Samson, B.K., Stephan, H.M., Songyikhangsuthor, K., Homma, K., Kiyono, Y. and Horie, T. (2009) Biochar Amendment Techniques for Upland Rice Production in Northern Laos: 1. Soil Physical Properties, Leaf SPAD and grain Yield. Field Crops Research, 111, 81-84. https://doi.org/10.1016/j.fcr.2008.10.008

[11] Varela Milla, O., Rivera, E.B., Huang, W.J., Chien, C. and Wang, Y.M. (2013) Agronomic Properties and Characterization of Rice Husk and Wood Biochars and Their Effect on the Growth of Water Spinach in a Field Test. Journal of Soil Science and Plant Nutrition, 13, 251-266.

https://doi.org/10.4067/S0718-95162013005000022

[12] Jeon, W.T., Seong, K.Y., Lee, J.K., Oh, I.S., Lee, Y.H. and Ok, Y.S. (2010) Effects of Green Manure and Carbonized Rice Husk on Soil Properties and Rice Growth. Korean Journal of Soil Science and Fertilizer, 43, 484-489.

[13] Haefele, S.M., Konboon, Y., Wongboon, W., Amarante, S., Maarifat, A.A., Pfeiffer, E.M. and Knoblauch, C. (2011) Effects and Fate of Biochar from Rice Residues in Rice-Based Systems. Field Crops Research, 121, 430-440. https://doi.org/10.1016/j.fcr.2011.01.014

[14] Wang, J., Zhang, M., Xiong, Z., Liu, P. and Pan, G. (2011) Effects of Biochar Addition on $\mathrm{N}_{2} \mathrm{O}$ and $\mathrm{CO}_{2}$ Emissions from Two Paddy Soils. Biology and Fertility of 
Soils, 47, 887-896. https://doi.org/10.1007/s00374-011-0595-8

[15] Ebaid, R.A. and El-Refaee, I.S. (2007) Utilization of Rice Husk as an Organic Fertilizer to Improve Productivity and Water Use Efficiency in Rice Fields. 8th African Crop Science Society Conference, El-Minia, 27-31 October 2007, 1923-1928.

[16] Sui, Y., Gao, J., Liu, C., Zhang, W., Lan, Y., Li, S. and Tang, L. (2016) Interactive Effects of Straw-Derived Biochar and N Fertilization on Soil C Storage and Rice Productivity in Rice Paddies of Northeast China. Science of the Total Environment, 544, 203-210. https://doi.org/10.1016/j.scitotenv.2015.11.079

[17] Kinoshita, N., Kato, M., Koyasaki, K., Kawashima, T., Nishimura, T., Hirayama, Y. and Kato, K. (2017) Identification of Quantitative Trait Loci for Rice Grain Quality and Yield-Related Traits in Two Closely Related Oryza sativa L. subsp. Japonica Cultivars Grown near the Northernmost Limit for Rice Paddy Cultivation. Breeding Science, 67, 191-206. https://doi.org/10.1270/jsbbs.16155

[18] Standard, A.S.T.M. (2002) D3172. Standard Practice for Proximate Analysis of Coal and Coke. Annual Book of ASTM Standards, 19428-2959.

[19] Wu, W., Yang, M., Feng, Q., McGrouther, K., Wang, H., Lu, H. and Chen, Y. (2012) Chemical Characterization of Rice Straw-Derived Biochar for Soil Amendment. Biomass and Bioenergy, 47, 268-276. https://doi.org/10.1016/j.biombioe.2012.09.034

[20] Konert, M. and Vandenberghe, J.E.F. (1997) Comparison of Laser Grain Size Analysis with Pipette and Sieve Analysis: A Solution for the Underestimation of the Clay Fraction. Sedimentology, 44, 523-535. https://doi.org/10.1046/j.1365-3091.1997.d01-38.x

[21] Klute, A. (1965) Laboratory Measurement of Hydraulic Conductivity of Saturated Soil. Methods of Soil Analysis. Part 1. Physical and Mineralogical Properties, Including Statistics of Measurement and Sampling, 210-221.

[22] Van Genuchten, M.T. (1980) A Closed-Form Equation for Predicting the Hydraulic Conductivity of Unsaturated Soils. Soil Science Society of America Journal, 44, 892-898. https://doi.org/10.2136/sssaj1980.03615995004400050002x

[23] Cataldo, D.A., Schrader, L.E. and Youngs, V.L. (1974) Analysis by Digestion and Colorimetric Assay of Total Nitrogen in Plant Tissues High in Nitrate. Crop Science, 14, 854-856. https://doi.org/10.2135/cropsci1974.0011183X001400060024x

[24] Murphy, J.A.M.E.S. and Riley, J.P. (1962) A Modified Single Solution Method for the Determination of Phosphate in Natural Waters. Analytica Chimica Acta, 27, 31-36. https://doi.org/10.1016/S0003-2670(00)88444-5

[25] Ohyama, T. (1991) Analytical Procedures of N, P, K Content in Plant and Manure Materials Using $\mathrm{H}_{2} \mathrm{SO}_{4}-\mathrm{H}_{2} \mathrm{O}_{2}$ Kjeldahl Digestion Method. Bulletin of the Faculty of Agriculture, Niigata University, 43, 111-120.

[26] Analytical Software (1996) Statistix for Windows: User's Manual. Analytical Software.

[27] Japanese Standard Association (2000) Test Method for Particle Size Distribution of Soils (JIS A 1204). Japanese Standard Association, Tokyo.

[28] Paethanom, A. and Yoshikawa, K. (2012) Influence of Pyrolysis Temperature on Rice Husk Char Characteristics and Its Tar Adsorption Capability. Energies, 5, 4941-4951. https://doi.org/10.3390/en5124941

[29] Kizito, S., Wu, S., Kirui, W.K., Lei, M., Lu, Q., Bah, H. and Dong, R. (2015) Evaluation of Slow Pyrolyzed Wood and Rice Husks Biochar for Adsorption of Ammo- 
nium Nitrogen from Piggery Manure Anaerobic Digestate Slurry. Science of the Total Environment, 505, 102-112. https://doi.org/10.1016/j.scitotenv.2014.09.096

[30] Jindo, K., Mizumoto, H., Sawada, Y. and Sonoki, T. (2014) Physical and Chemical Characterization of Biochars Derived from Different Agricultural Residues. Biogeosciences, 11, 6613. https://doi.org/10.5194/bg-11-6613-2014

[31] Lai, W.Y., Lai, C.M., Ke, G.R., Chung, R.S., Chen, C.T., Cheng, C.H. and Chen, C.C. (2013) The Effects of Woodchip Biochar Application on Crop Yield, Carbon Sequestration and Greenhouse Gas Emissions from Soils Planted with Rice or Leaf Beet. Journal of the Taiwan Institute of Chemical Engineers, 44, 1039-1044. https://doi.org/10.1016/j.jtice.2013.06.028

[32] Huang, M., Yang, L., Qin, H., Jiang, L. and Zou, Y. (2013) Quantifying the Effect of Biochar Amendment on Soil Quality and Crop Productivity in Chinese Rice Paddies. Field Crops Research, 154, 172-177. https://doi.org/10.1016/j.fcr.2013.08.010

[33] Chen, J., Liu, X., Zheng, J., Zhang, B., Lu, H., Chi, Z. and Wang, J. (2013) Biochar Soil Amendment Increased Bacterial But Decreased Fungal Gene Abundance with Shifts in Community Structure in a Slightly Acid Rice Paddy from Southwest China. Applied Soil Ecology, 71, 33-44. https://doi.org/10.1016/j.apsoil.2013.05.003

[34] Herath, H.M.S.K., Camps-Arbestain, M. and Hedley, M. (2013) Effect of Biochar on Soil Physical Properties in Two Contrasting Soils: An Alfisol and an Andisol. Geoderma, 209, 188-197. https://doi.org/10.1016/j.geoderma.2013.06.016

[35] Munda, S., Nayak, A.K., Mishra, P.N., Bhattacharyya, P., Mohanty, S., Kumar, A. and Adak, T. (2016) Combined Application of Rice Husk Biochar and Fly Ash Improved the Yield of Lowland Rice. Soil Research, 54, 451-459. https://doi.org/10.1071/SR15295

[36] Major, J., Rondon, M., Molina, D., Riha, S.J. and Lehmann, J. (2010) Maize Yield and Nutrition during 4 Years after Biochar Application to a Colombian Savanna Oxisol. Plant and Soil, 333, 117-128. https://doi.org/10.1007/s11104-010-0327-0

[37] Jeffery, S., Verheijen, F.G., Van Der Velde, M. and Bastos, A.C. (2011) A Quantitative Review of the Effects of Biochar Application to Soils on Crop Productivity Using Meta-Analysis. Agriculture, Ecosystems \& Environment, 144, 175-187. https://doi.org/10.1016/j.agee.2011.08.015

[38] Yamato, M., Okimori, Y., Wibowo, I.F., Anshori, S. and Ogawa, M. (2006) Effects of the Application of Charred Bark of Acacia mangium on the Yield of Maize [Zea mays], Cowpea [Vigna unguiculata] and Peanut [Arachis hypogaea], and Soil Chemical Properties in South Sumatra, Indonesia. Soil Science and Plant Nutrition (Japan), 52, 489-495. https://doi.org/10.1111/j.1747-0765.2006.00065.x

[39] Downie, A., Crosky, A. and Munroe, P. (2009) Physical Properties of Biochar. Biochar for Environmental Management: Science and Technology, 13-32.

[40] Hussain, M., Farooq, M., Nawaz, A., Al-Sadi, A.M., Solaiman, Z.M., Alghamdi, S.S. and Siddique, K.H. (2017) Biochar for Crop Production: Potential Benefits and Risks. Journal of Soils and Sediments, 17, 685-716. https://doi.org/10.1007/s11368-016-1360-2

[41] Zhang, X., Wang, H., He, L., Lu, K., Sarmah, A., Li, J. and Huang, H. (2013) Using Biochar for Remediation of Soils Contaminated with Heavy Metals and Organic Pollutants. Environmental Science and Pollution Research, 20, 8472-8483. https://doi.org/10.1007/s11356-013-1659-0

[42] Chan, K.Y., Van Zwieten, L., Meszaros, I., Downie, A. and Joseph, S. (2008) Agronomic Values of Greenwaste Biochar as a Soil Amendment. Soil Research, 45, 
629-634. https://doi.org/10.1071/SR07109

[43] Peng, X., Ye, L.L., Wang, C.H., Zhou, H. and Sun, B. (2011) Temperature- and Duration-Dependent Rice Straw-Derived Biochar: Characteristics and Its Effects on Soil Properties of an Ultisol in Southern China. Soil and Tillage Research, 112, 159-166. https://doi.org/10.1016/j.still.2011.01.002

[44] Alburquerque, J.A., Calero, J.M., Barrón, V., Torrent, J., del Campillo, M.C., Gallardo, A. and Villar, R. (2014) Effects of Biochars Produced from Different Feedstocks on Soil Properties and Sunflower Growth. Journal of Plant Nutrition and Soil Science, 177, 16-25. https://doi.org/10.1002/jpln.201200652

[45] Shackley, S., Carter, S., Knowles, T., Middelink, E., Haefele, S., Sohi, S. and Haszeldine, S. (2012) Sustainable Gasification-Biochar Systems? A Case-Study of Rice-Husk Gasification in Cambodia, Part I: Context, Chemical Properties, Environmental and Health and Safety Issues. Energy Policy, 42, 49-58.

https://doi.org/10.1016/j.enpol.2011.11.026

[46] Kloss, S., Zehetner, F., Dellantonio, A., Hamid, R., Ottner, F., Liedtke, V. and Soja, G. (2012) Characterization of Slow Pyrolysis Biochars: Effects of Feedstocks and Pyrolysis Temperature on Biochar Properties. Journal of Environmental Quality, 41, 990-1000. https://doi.org/10.2134/jeq2011.0070

[47] Laghari, M., Mirjat, M.S., Hu, Z., Fazal, S., Xiao, B., Hu, M. and Guo, D. (2015) Effects of Biochar Application Rate on Sandy Desert Soil Properties and Sorghum Growth. Catena, 135, 313-320. https://doi.org/10.1016/j.catena.2015.08.013

[48] Emmanuel, D. and Peter, R.R. (1995) Aluminum Toxicity and Tolerance in Plants. Plant Physiology, 107, 315-321. https://doi.org/10.1016/j.catena.2015.08.013

Submit or recommend next manuscript to SCIRP and we will provide best service for you:

Accepting pre-submission inquiries through Email, Facebook, LinkedIn, Twitter, etc. A wide selection of journals (inclusive of 9 subjects, more than 200 journals)

Providing 24-hour high-quality service

User-friendly online submission system

Fair and swift peer-review system

Efficient typesetting and proofreading procedure

Display of the result of downloads and visits, as well as the number of cited articles

Maximum dissemination of your research work

Submit your manuscript at: http://papersubmission.scirp.org/

Orcontact as@scirp.org 